Мазур Екатерина Васильевна - кандидат экономических наук, доцент, заведующая кафедрой аграрного менеджмента, Винницкий национальный аграрный университет (г. Винница, ул. Солнечная, 3)

E-mail: kv_mazur@ukr.net

ORCID iD https://orcid.org/0000-0002-1137-3422

Стаття надійшла до редакції 02.11.2019 р.

Фахове рецензування: 10.11.2019 р.

Бібліографічний опис для цитування:

Барабаш Л. О., Мазур К. В. Розвиток промислового садівництва в умовах євроінтеграційних процесів. Економіка АПК. 2019. № 12. С. 69 - 79.

UDC 338. 43 (479.25)

JEL Classification: Q1; Q10; Q13

DOI: https://doi.org/10.32317/2221-1055.201912079

L.R. KHACHATRYAN, candidate of economic sciences

\title{
Current problems of the agricultural market and development prospects on an example of the Republic of Armenia*
}

The purpose of the article is to assess current state of the agricultural market of the Republic of Armenia and identify existing problems that impede the sector's development, specifically regarding conditions for the sale of agricultural products, structural changes in the value chain, as well as peasant farms' development.

Research methods. The study is based on the study, analysis and generalization of open publications, works of local and foreign scientists. Research was based on popular scientific and economic methods, scientific works of foreign scientists on issues of agricultural market, agricultural marketing, problems related to food security. In the research process were used the following scientific methods: dialectical, abstract and logical, system analysis.

Research results. The article discusses the essence of the introduction of advanced technologies in the agricultural sector, analyses and presents proposals for the institutional prerequisites of the social and economic advantages of the private sector, considers the problems of selling vegetables and fruits by small points on sales and their cooperation with farms. Proposals on organization of purchases, collection of vegetables and fruits, introduction of storage, as well as refrigerating stores for storage and further sale in own food counter were presented, and examples of organization of sale of vegetables and fruits, concurringly through guest houses, hostels, were highlighted.

Elements of scientific novelty. There were presented proposals on the creation of storage and refrigeration facilities for the reception and sale of fruits and vegetables in their own points on sales, proposals on legislative changes to limit the sale of vegetables and fruits by hypermarkets for a certain period of time of the day (especially during the day), which would lead to the promotion of sales by local food stalls and markets, as well as legislative changes in the tax code of the Republic of Armenia aimed at the reduction of an interest rate of value added tax in the sale of vegetables and fruits, which contribute to the improvement of the economic efficiency of the sector.

Practical significance. The submitted offers on legislative changes and organizing of points on sale of vegetables and fruit will lead to the development of small business, agritourism and will increase cost efficiency of farms that will contribute to the reduction of prices in sales chains. Refs.: 12.

Keywords: agriculture; sales; imports; food; competition; agritourism; supply.

Khachatryan Levon Ruben - candidate of economic sciences, researcher fellow, European University (10, Davit Anhaght St., Yerevan, Republic of Armenia)

E-mail: levonkhach@yahoo.com

Scientific problem. An important prerequisite for the development of agriculture is the presence of an internal and external market, stable demand and solvent society. The agri-

\footnotetext{
* This work was supported by the RA MES Science Committee, in the frames of the research project № 19YR-5B026.

(C) L.R. Khachatryan, 2019
}

cultural sector is not yet so developed to achieve the necessary level of profit and production volumes without state support.

The agricultural sector is most affected by factors such as drought, hail, frost, etc., leading to risks. Currently, a pilot insurance program is being implemented in the Republic of Armenia in agriculture, which is a deterrent 
mechanism for compensation of losses and risks. This problem impedes agricultural development, while reducing farm incomes, increasing food prices and market deficits, which have led to increased imports of certain goods.

For many years, along with the development and implementation of reforms in the country, the necessary infrastructures have not been created in parallel, the provision of funds for the corresponding demand of resources, modern technical and technological solutions that would contribute to increasing the profitability of the sector. The Republic of Armenia is a member of the EAEU and carries out foreign trade in agricultural products with the EAEU member countries, mainly with the Russian Federation. From this point of view, the demand acting on the market of the Russian Federation, as well as price policy, currency fluctuations have a great influence on the activities of both agricultural producers and exporting entities of the Republic of Armenia. In this regard, the problem of the sales of fruits and vegetables in the market is relevant as in the sales chain mediation affects the sales prices.

Analysis of recent research and publications. The problems of the agricultural market and its development are always relevant, and the work of a number of Russian economists $[2,5,6,10,12]$ is devoted to the study and determination of possible solutions, as the preferences of the population change as the market develops, while at the same time, there is a need to produce high-quality agricultural products that will be competitive and affordable. However, these works do not present a comprehensive solution to the problems that can be introduced into the economy of the Republic of Armenia.

The purpose of the article is to assess current state of the agricultural market of the Republic of Armenia and identify existing problems that impede the sector's development, specifically regarding conditions for the sale of agricultural products, structural changes in the value chain, as well as peasant farms' development.

Research methodology. The study analyses the main indicators of food self-sufficiency, the level of which is still low. At the same time, a comparative analysis revealed the trends of food prices in the domestic market, which led to a tendency of low inflation, which, combined with the volume of produc- tion produced by farms, led to a decrease in their income. At the same time, abstract logistic analysis analysed the problems of farms selling fruits and vegetables, studied the experience of the Russian market, according to which it would be advisable to organize supply centres and deliver vegetables and fruits to their own points of sale or to supply various establishments.

Research results. Agriculture does not yet provide sustainable profitability and attractiveness, since the rate of working capital is slow, financial resources are expensive or inaccessible, in many cases, depending on climatic conditions, losses are inevitable, the socio-economic situation in farms is unsatisfactory, sowing areas are small. To improve the situation, appropriate financial resources and state support are needed [6, p. 49].

Technological changes, the development of agriculture and the agro-industrial complex, and the centralization of processing entities indirectly contributed to the reduction of labour resources, lower living standards in rural areas, in the absence of infrastructure and migration, medical facilities are incomplete and inefficient, industrial entities do not work. In many cases, agriculture is considered to be disadvantageous for the rural population, since farms are organized on small plots of land and they are under inefficient cultivation [8, p. 118].

State support of the agricultural sector has always been the subject of academic discussion by professionals and the general public, especially the assessment of its effectiveness, since funding is limited due to the associated risks, and the assessment of effectiveness is difficult due to adverse climate conditions. It is obvious that the industry needs private financing, state support and credit resources, which should ensure development, but the pace of development is still slow. Thus, problems arise for creating added value by providing new technological solutions, applying innovations, ensuring efficiency and development. Economic efficiency and development are due to improved product quality, innovation and scientific and technical results, increased productivity and production volumes, diversification and horizontal integration, vertical integration, cooperation and favourable investment conditions for business, which will lead to an improvement in the life and social conditions of the rural population, ensuring 
appropriate infrastructure, reducing population migration [7, p. 12-13].

The material and socio-economic welfare of the farms, as well as the population, is determined by the development of the sector and the use of the latest technologies in this sector, which, in turn, will ensure the appropriate level of economic security. Improving the economic efficiency of the agricultural sector has been and remains a priority issue for the country and the problems of the agricultural market, in particular, competition in the market requires significant resources, taking into account the volume of imported agricultural products. Thus, the issue of food security must be considered from the point of view of the physical provision of the population with own food production, since in many cases without state support, a subsidy program, etc. it is impossible to ensure economic efficiency [2, pp. 91-92].

Currently, there are problems with the agricultural knowledge and skills of farmers in Armenia, as they lack basic knowledge about animal husbandry, horticulture and crop production, as a result, farms cannot provide maximum profitability, resources are used inefficiently, and the state's role is needed and is important in providing consulting services and ensuring their accessibility to the villagers. As a result of the uneven and disproportionate distribution of agricultural land, the cultivated areas and orchards of farms are small, and the gross harvest is low, because of which gross income also is low. Considering the above mentioned, in the framework of the relevant legislative initiatives already implemented by the Government of the Republic of Armenia and the National Assembly, it is planned to conduct auctions for the sale of land through a land auction and the expansion of plots, which will increase the sown area and the gross volume of crops. At the same time, the state organizes and implements consultative and informational programs aimed at developing rural communities, but the results can be evaluated in a few years.

According to statistics, the number of farms in Armenia in 2017 year was 873 thousand, of which 463.6 thousand were specialized in crop production and 412.4 thousand in livestock farming [11, p. 302]. The number of employees in the industry in 2018 year amounted to 225.4 thousand [1, p. 12].
In order to ensure the food security of the Republic of Armenia, along with the food produced in the country, its wide assortment is also imported, since the volumes of domestic production are not sufficient. An indicator of the country's food security is the national food balance and the level of self-sufficiency. Selfsufficiency level in 2018 year for wheat amounted to $31.5 \%$, rye $65.6 \%$, oats $85.6 \%$, maize $9.8 \%$, carrots $84.9 \%$, green peas $22.7 \%$, hazel nuts $69.5 \%$ berries $69.2 \%$. peas - $23 \%$, beans - $83.1 \%$, lentils - $7.1 \%$, chick-peas $20.9 \%$, vegetable oil - $2.2 \%$, sugar - $68.6 \%$, milk - $86.8 \%$, beef $-89.2 \%$, pork - $53.3 \%$, poultry meat $26.2 \%$, and the rest of the assortment is self-sufficient [1, p. 68-70].

Studying the food price index, can notice that there is some price stability, but there is no downward trend, and so this figure in 2017 year was $104.0 \%$, in 2018 year - 102.5\%, and in 2019 in the second quarter of compared with the same quarter last year, the index was $104.6 \%$. Unlike the food price index, the agricultural producer price index recorded an increase in $13.1 \%$ only in 2018 year, but in 2017 year the index was $100.8 \%$, and in 2019 year during the second quarter compared with the same quarter of the previous year it was $97.1 \%$ [1, p. 22], thus keeping production volumes not to change, contributing to lower incomes of farms.

Indicators of food imports in 2018 year also problematic in particular, the volume of wheat amounted to 329.3 thousand tons, the volume of sugar - 23.7 thousand tons, poultry meat - 32.8 thousand tons, beef - 4.86 thousand tons, pork - 8.89 thousand tons, milk 7.49 thousand tons, vegetables -23.8 thousand tons, fruits -83.89 thousand tons, melons - 2 thousand tons [1, p. 60].

It should be noted that over the past five years, the dynamics of imports has practically persisted, which negatively affects the development of the industry. The presented figures can be evaluated negatively, which is associated with a disproportionate distribution of land for cultivation in the Republic of Armenia, as well as a low level of provision with agricultural machinery etc. The problems of milk and meat production are associated with animal husbandry, since the reduction of livestock, as well as resources (production and financial) for the organizing of production are limited, forage is expensive. All this impedes the development of agriculture and requires 
an appropriate policy for developing integrated solutions through reforms.

At the same time, in the process of developing business and agriculture, processes of vertical integration into the agro-industrial complex have been outlined by economic entities specializing in the export of food and agricultural products, in particular, in creating their own orchards, livestock farms and providing their own raw materials for production, the purpose of which is to reduce costs for working capital and providing food security. "Spayka" LLC, “Euroterm" LLC, "Arm-Berry" LLC, "Tamara Fruit" CJSC and others actively participate in this process, which, according to the state support program, created "intensive" orchards with anti-hail nets, drip irrigation systems, due to the availability of own equipment for land processing, they provide high productivity and quality, economic efficiency and job creation in the village.

Beside it is noteworthy achievements in the meat and dairy sector "Arzni Pedigree Poultry Farm, Cattle and Pig Farm" OJSC, "Bandivan Kat" LLC, "Dili" LLC, "Marila" LLC created livestock farms by importing and raising highbreed animals. The activities of "Redi Steady" LLC (Art Lunch) and "Eremyan Projects" LLC specializing in restaurants and catering, which organized and built pig farms and cattle farms to achieve self-sufficiency in raw materials.

The sales chain in the agricultural market in Armenia is still underdeveloped, since mediation mainly exists in two chains, in particular, the intermediate links in the chain from producer to seller affect the final cost, and as a result, the consumer buys agriculture products at a high price, and the income of farms are getting low. Currently because of population centralization on Yerevan city the big share of trade turnover is implemented there so the entities and groceries are doing wholesale purchase for fruits and vegetables from two wholesale markets one from Yerevan named Malatia bazar and the second one from Ararat marz where farmers and middleman are trading. However, it should be noted that in addition to mediation, indirect mediation (middleman) provides additional jobs and income, which also has social significance for the country. There are problems with infrastructure and logistics, in particular, the lack of vehicles, refrigeration facilities, where, after harvest, vegetables and fruits will be collected and stored for subsequent market entry. At the same time, the presence of large stores, especially supermarkets, negatively affects the work of small groceries in connection with competition, the latter being closed, and the creation of new groceries becoming unprofitable.

Today, in the agricultural market, the sales process is carried out mainly by large supermarket chains, and due to the limited purchasing ability, farms encounter problems in selling products, and in many cases the product is sold at a relatively low price and becomes economically inefficient. Taking into account the volume of imports, the main emphasis should be placed on the development of agriculture through import substitution through the development of domestic production, which may be associated with increased demand that ensures high quality agricultural products [12, p. 5]. In many cases, with free market relations, the sales of agricultural products by large trading chains is considered to be dominant, and unequal competition and monopoly arise. In the implementation process, there are obstacles to the formation of prices and infrastructure due to the lack of mediation between producers and consumers, insufficient level of market infrastructure and government support. As a result, in the case of diversified sales in the sales chain, in many cases due to financial problems and in the case of perishable products, farms are not able to sell products locally, they sell through various chains and do not provide a sufficient level of income [5, p. 269-270].

Among the problems for the development of the agricultural market is the insufficient socio-economic situation of the population, especially in rural areas, as well as the use of the diet in accordance with physiological norms. The sector that is responsible for the food security of the country operates in conditions of a low level of material and technical support, affordable infrastructure and social security, a low level and experience in initiating entrepreneurship, and insufficient government support. At the same time, the economic efficiency of entities involved in the sector depends on internal and external factors, in particular on climatic conditions, fiscal and monetary policies, especially currency fluctuations, inflation regulation, restrictions on imported food products, protection of property rights, as well as from internal organizational factors of management 
[3, p. 275-276]. Thus, improving the business environment for entities engaged in agricultural production and purchase of raw materials, is also aimed at improving the social situation of farms.

The problem of food security is associated with low incomes and solvency of consumers, which leads to a decrease in solvent demand and leads to price fixing or to some decline. At the same time, in case of an increase in production costs and their compensation, producers incur losses that lead to higher prices, which contributes to the deterioration of the consumer market [3, p. 277]. Currently, this situation is observed in the consumer market of the Republic of Armenia, which continues and requires comprehensive solutions, in particular, the exclusion of intentional interference in monetary policy on the exchange rate, a comprehensive study of the food market, especially the vegetable and food sector, studies of suppliers and points of sales and their dominant intermediary positions and, if available, the use of administrative penalties etc. As noted earlier, the main shopping centres of Yerevan are located in almost all communities and indirectly occupy a monopoly position in the process of selling agricultural products, as consumers visit the shopping centre from one place and buy food and other consumer goods, negatively resulting in small groceries. Based on the foregoing, we believe that it is advisable to apply sales restrictions for large shopping centres for a certain period of time (especially from the morning to daytime) in order to carry out the sales process and its growth at groceries at certain hours of times, while obliging them to provide adequate sanitary conditions for storing agricultural products. It should be noted that the process of organizing the sales of agricultural products in open pavilions and on the street is carried out in poor sanitary conditions, which is a food safety problem, which requires the installation of pavilions and closed shops in communities and the installation of appropriate refrigerators for agriculture products.

Market studies and analysis show that a large number of economic entities are involved in this sector, which are purchasers and sellers of agricultural products, in particular through a distribution network and large retail outlets that sell goods as a legal entity, where the annual sales turnover exceeds 58.35 million drams, are payers of VAT and pay $20 \%$ VAT [4] from products sold above the threshold, while ensuring a low level of profitability. Thus, studying the policy of applying VAT by the EAEU countries in the field of agricultural products sales, in particular in the Russian Federation [9], it is proposed in the Republic of Armenia to reduce a VAT rate of $10 \%$ levied on the sale of agricultural products, which will contribute to the accumulation of financial resources and will be aimed at reducing market prices for the purchase of agricultural products.

In conditions of free market relations, however, in conditions of inferior infrastructure for sales and limited demand, rural and agricultural development, for increasing the profitability of small farms and creating added value are possible due to the vertical integration of farms with an agritourism subcomplex, namely, the processing of agricultural products in local communities or cities and selling the products in local guest houses and hotels [10, pp. 130-131], contributing the development of tourism by organizing small hotel complexes and guest houses. Besides it is important organization of production of ecologically clean agricultural products and organization of their sales on the place, which will contribute to improving the socioeconomic situation of rural communities.

In order to ensure food security and improve the socio-economic situation of farms, an appropriate infrastructure for implementation is needed, in particular, it is necessary to create commercial organizations for the purchase of agricultural products and organize sales through their own groceries. It is advisable to create purchase points in the Armavir, Aragatsotn, Gegharkunik and Tavush marzes equipped with warehouses, refrigerated warehouses where the fruits and vegetables will be collected and purchased from the farms, in some cases it will collected directly from orchards or fields, will be stored, and then delivered by appropriate vehicles to their own and other private groceries in Yerevan and other large cities of different marzes of Armenia.

At the same time, it is possible to organize sales of agriculture products in the framework of cooperation with hotels, guest houses and restaurants, kindergartens, orphanages both in the marzes of Armenia and in the city of Yerevan. It should be noted that in the marzes there are different buildings from the times of 
the USSR that can be used as warehouses in case of reconstruction, there are still old refrigeration facilities that are either in poor condition or not used and can be restored or restarted, which will lead to a reduction in capital investment and costs. The Government can provide support here, especially in the context of free allocation of land, extension of customs duties and VAT on the import of equipment, as well as support under state financial lending programs.

Conclusions. Summarizing the presented problems of the agricultural sector and suggestions for their solution, it can be noted that, in comparison with regional markets, the agricultural market of the Republic of Armenia is at a development stage, as the infrastructure and the supply chain of agricultural products are

\section{Literature}

1. Бедность и продовольственная обеспеченность, январь-июнь 2019 года. Статистический бюллетень. Ереван : CK PA, 2019. С. 12.

2. Власова Н. В. Конкурентоспособность сельского хозяйства как путь его эффективного развития в Российской экономике. Проблемы и перспективы развития аграрного рынка : сб. науч. ст. / под ред. М. П. Дулина [и др.]. Краснодар, 2013. 252 с.

3. Еримизина М. И. Рынок аграрной продукции Крыма: состояние, перспективы развития, Вісник Житомирського державного технологічного університету. Серія: Економічні науки. 2005. № 3(33). С. 275-276.

4. Налоговый кодекс Республики Армения : Закон Республики Армения от 04 октября 2016 г., № 3Р-165-Н : принят Национальным Собранием РА 04 октября 2016 г. / Системы правовой информации Армении. $3 А О$ «Официальные ведомости». Ереван, 2019.

5. Иванова Н. В. Известия Нижневолжского агроуниверситетского комплекса: наука и высшее профессиональное образование. 2011. Вып. 4 (24). 318 с.

6. Малейченко В. Н. Институциональные и экономические проблемы развития капитализма в сельском хозяйстве. Проблемы и перспективы развития аграрного рынка: сб. науч. cm. / под ред. М. П. Дулина [и др.]. Краснодар, 2013. 252 с.

7. Минасов М., Шакирова А. Аграрный сектор экономики: состояние, проблемы, факторы и условия устойчивого развития. Экономика и управление: научно-практический журнал. 2014. № 3. 120 с

8. Нечипоренко О. В. Социальные аспекты реструктуризации аграрной сферы: общие тенденции и риски поляризации социально-экономического пространства. Проблемы и перспективы развития сельского хозяйства и сельских территорий : сборник статей VI Международной научнопрактической конференции; ФГБОУ ВО Саратовский ГАУ. Саратов, 2017. 197 с.

9. Об утверждении перечней кодов видов продовольственных товаров и товаров для детей, облагаемых налогом на добавленную стоимость по налоговой ставке 10 процентов. Постановление от 31 декабря 2004 г. № 90. КонсультантПлюс. URL : http://www.consultant.ru/cons/cgi/ online . cgi?req=doc\&base $=\mathrm{LAW} \& \mathrm{n}=313142 \& \mathrm{fld}=134 \& \mathrm{dst}=101518$, 0\&rnd=0.23736094248594597\#01437476642775568. (Дата обращения: 28.10.2019).

10. Петрова И. В., Котельникова Е. А. Проблемы и перспективы инновационного развития сельских территорий Саратовской области. Проблемы и перспективы развития сельского хозяйства и сельских территорий : сборник статей VI Международной научно-практической конференции; ФГБОУ ВО Саратовский ГАУ. Саратов, 2017. 197 с. undeveloped, the incomes of population are not high, import volumes are decreasing slightly etc. The above problems require targeted assistance to the private sector in the implementation of investment projects for the organization of logistics infrastructure in the domestic market, for which the role of the state in maintaining an effective agricultural policy is important. The study shows that in order to ensure economic efficiency in the industry for the sales of fruits and vegetables, there is a need to help resolve issues related to lowering the VAT rate on sales, protecting the rights of small groceries and providing preferential conditions for sales for a certain time range (schedule), which will contribute to increase in income and improve the socio-economic status of farms.

\section{References}

1. Bednost $i$ prodovolstvennaja obespechennost, janvarijun 2019 goda: statisticheskij bjulleten [Poverty and food security, January-June 2019: statistical bulletin]. (2019). Erevan: SK RA. [In Russian].

2. Vlasova, N.V. (2013). Konkurentosposobnost selskogo hozjajstva kak put ego jeffektivnogo razvitija $v$ Rossijskoj jekonomike [Competitiveness of agriculture as a way of its effective development in the Russian economy]. Problemy $i$ perspektivy razvitija agrarnogo rynka: Sb. nauch. st. - Problems and prospects for the development of the agricultural market: collection of scientific articles. Krasnodar [In Russian].

3. Erimizina, M.I. (2005). Rynok agrarnoj produkcii kryma: sostojanie, perspektivy razvitija [Crimean agrarian market: state, development prospects]. Visnik Zhitomirskogo derzhavnogo tehnologichnogo universitetu. Serija: Ekonomichni nauki, 3 (33), pp. 275-276 [In Russian].

4. Zakon Respubliki Armenija "Nalogovyj kodeks Respubliki Armenija”, 04 oktjabrja 2016 g., № ZR-165-N [Tax Code of the Republic of Armenia: Law of the Republic of Armenia dated 4.10.2016, No. 3P-165-H]. (2019). Erevan: Sistemy pravovoj informacii Armenii. ZAO “Oficialnye vedomosti” [In Russian].

5. Ivanova, N.V. (2011). Izvestija Nizhnevolzhskogo agrouniversitetskogo kompleksa: nauka i vysshee professionalnoe obrazovanie [Reports of Nizhnevolzhskyi agro-university complex: science and higher professional education]. Vol. 4 (24) [In Russian].

6. Malejchenko, V.N. (2013). Institucionalnye i jekonomicheskie problemy razvitija kapitalizma $v$ selskom hozjajstve [Institutional and economic problems of the development of capitalism in agriculture]. Problemy i perspektivy razvitija agrarnogo rynka: Sb. nauch. st. - Problems and prospects for the development of the agricultural market: collection of scientific articles. Krasnodar [In Russian].

7. Minasov, M. \& Shakirova, A. (2014). Agrarnyj sektor jekonomiki: sostojanie, problemy, faktory i uslovija ustojchivogo razvitija [Agricultural sector of the economy: state, problems, factors and conditions of sustainable development]. Jekonomika $i$ upravlenie: nauchno-prakticheskij zhurnal, 3 [In Russian].

8. Nechiporenko, O.V. (2017). Socialnye aspekty restrukturizacii agrarnoj sfery: obshhie tendencii i riski poljarizacii socialno-jekonomicheskogo prostranstva [Social aspects of agricultural restructuring: general trends and polarization risks of the socio-economic space]. Problemy i perspektivy razvitija selskogo hozjajstva i selskih territorij: Sbornik statej VI Mezhdunarodnoj nauchno-prakticheskoj konferencii - Problems and prospects for the development of agriculture and rural areas: collection of articles of the VI International Scientific and Practical Conference. Saratov: FGBOU VO Saratovskij GAU [In Russian]. 
11. Статистический ежегодник Армении. 2018. Ереван : CK PA, 2018. 592 c.

12. Стратегические направления развития сельского хозяйства России в условиях углубления интеграции в ЕАЭС / И. Г. Ушачёв, А. Г. Папцов, Н.К. Долгушкин, А. Ф. Серков, В. В. Маслова, В. С. Чекалин. Москва : РАН, 2017. 48 с.
9. Ob utverzhdenii perechnej kodov vidov prodovolstvennyh tovarov $\mathrm{i}$ tovarov dlja detej, oblagaemyh nalogom na dobavlennuju stoimost po nalogovoj stavke 10 procentov: Postanovlenie ot 31 dekabrja 2004 g. № 90 [On approval of lists of codes of types of food and goods for children taxed with value added tax at a 10 percent tax rate: Decree dated 31.12.2004, No. 90]. KonsultantPljus. Retrieved from: http: / / www.consultant.ru/cons/cgi/online.cgi?req=doc\&base= LAW\&n $=313142 \&$ fld $=134 \& d s t=101518$, $\&$ \&rnd $=0.23736094248594$ 597\#01437476642775568 [In Russian].

10. Petrova, I.V. \& Kotelnikova, E.A. (2017). Problemy i perspektivy innovacionnogo razvitija sel'skih territorij Saratovskoj oblasti [Problems and prospects of innovative development of rural territories of the Saratov region]. Problemy $i$ perspektivy razvitija selskogo hozjajstva $i$ selskih territorij: Sbornik statej VI Mezhdunarodnoj nauchno-prakticheskoj konferencii - Problems and prospects for the development of agriculture and rural areas: collection of articles of the VI International Scientific and Practical Conference. Saratov: FGBOU VO Saratovskij GAU [In Russian].

11. Statisticheskij ezhegodnik Armenii [Statistical yearbook of Armenia]. (2018). Erevan: SK RA [In Russian].

12. Ushachjov, I.G., Papcov, A.G., Dolgushkin, N.K., Serkov, A.F., Maslova, V.V., \& Chekalin, V.S. (2017). Strategicheskie napravlenija razvitija selskogo hozjajstva Rossii $v$ uslovijah uglublenija integracii $v$ EAJeS [Strategic directions of agricultural development in Russia in context of deepening integration in the EAEU]. Moscow: RAN [In Russian].

\section{Хачатрян Л.Р. Актуальні проблеми аграрного ринку та перспективи розвитку на прикладі Республіки Вірменія}

Мета статmі - визначити поточний стан аграрного ринку Республіки Вірменія, виявити існуючі проблеми, що перешкоджають розвитку аграрного сектору, стосовно умов реалізації сільськогосподарської продукції, структурних змін у ланцюгу створення цінності, а також розвитку селянських господарств.

Методика дослідження. Базується на вивченні, аналізі й узагальненні матеріалів відкритих публікацій, праць вітчизняних і зарубіжних учених. За основу досліджень слугували загальнонаукові та економічні методи, наукові роботи іноземних дослідників з питань аграрного ринку, аграрного маркетингу, висвітлення проблем, пов'язаних із продовольчою безпекою. У процесі дослідження використано методи: діалектичний, абстрактно-логічний, системного аналізу.

Результати дослідження. Розглянуто особливості впровадження передових технологій в аграрному секторі, проаналізовано інституціональні передумови соціально-економічних переваг приватного сектору, окреслено проблеми реалізації овочів і фруктів малими торговими точками та їх співпраці з селянськими господарствами. Сформовано пропозиції щодо здійснення закупівель, збору овочів і фруктів, організації складських та холодильних господарств для зберігання й подальшої реалізації у власних продуктових точках, наведено приклади організації реалізації овочів і фруктів, зокрема через гостьові будинки та готелі.

Елементи наукової новизни. Обгрунтовано пропозиції відносно створення складських і холодильних господарств по прийому і реалізації овочів і фруктів у власних пунктах, пропозиції по обмеженню реалізації овочів і фруктів у гіпермаркетах в певні години впродовж дня, що забезпечить продаж такої продукції місцевими продуктовими точками $і$ на ринках, а також пропозиції внесення законодавчих змін до Податкового кодексу Республіки Вірменія для зниження процентної ставки при реалізації овочів і фруктів, що сприятиме підвищенню економічної ефективності агросектору.

Практична значущість. Авторські пропозиції щодо організації реалізаційних пунктів зі збуту овочів і фруктів та внесення відповідних законодавчих змін сприятимуть розвитку малого підприємництва, розвитку агротуризму, підвищенню економічної ефективності селянських господарств, що сприятиме зниженню цін реалізації в ланцюгу вартості. Бібліогр.: 12.

Ключові слова: сільське господарство; реалізація; імпорт; продовольство; конкуренція; агротуризм; постачання.

Хачатрян Левон Рубенович - кандидат економічних наук, науковий співробітник, Європейський університет (Республіка Вірменія, м. Єреван, вул. Давида Анахті, б. 10)

E-mail: levonkhach@yahoo.com

\section{Хачатрян Л.Р. Актуальные проблемы аграрного рынка и перспективы развития на примере Республики Армения}

Цель статьи - определить текущее состояние аграрного рынка Республики Армения, выявить проблемы, препятствующие развитию аграрного сектора, относительно условий реализации сельскохозяйственной продукции, структурных изменений в цепочке создания ченности, а также развития крестьянских хозяйств.

Методика исследования. Базируется на изучении, анализе и обобщении материалов открытых публикаций, трудов отечественных и зарубежных учёных. Основой исследований послужили общенаучные и экономические методы, научные работы иностранных исследователей по вопросам аграрного рынка, аграрного маркетинга, освещение проблем, связанных с продовольственной безопасностью. В процессе исследования использованы методы: диалектический, абстрактнологический, системного анализа.

Результаты исследования. Рассмотрены особенности внедрения передовых технологий в аграрном секторе, проанализированы институциональные предпосылки социально-экономических преимуществ частного сектора, очерчены проблемы реализации овощей и фруктов малыми торговыми точками и их сотрудничества с крестьянскими хозяйствами. Сформированы предложения по осуществлению закупок, сбору овощей и фруктов, организации складских и холодильных хозяйств для хранения и дальнейшей реализации в собственных продуктовых точках, приведены примеры организации реализации овощей и фруктов, в частности через гостевые дома и гостиницы.

Элементы научной новизны. Обоснованы предложения относительно создания складских и холодильных хозяйств по приему и реализации овощей и фруктов в собственных пунктах, предложения по ограничению реализации овощей и фрук- 
тов в гипермаркетах в определенные часы на протяжении дня, что обеспечит продажу такой продукции местными продуктовыми точками и на рынках, а также предложения по внесению законодательных изменений в Налоговый кодекс Республики Армения для снижения процентной ставки при реализации овощей и фруктов, что будет способствовать повышению экономической эффективности агросектора.

Практическая значимость. Авторские предложения по организации реализационных пунктов по сбыту овощей и фруктов, а также по внесению соответствующих законодательных изменений будут способствовать развитию малого предпринимательства, агротуризма, повышению экономической эффективности крестьянских хозяйств, что будет способствовать снижению цен реализации в цепочке стоимости. Библиогр.: 12.

Ключевые слова: сельское хозяйство; реализация; импорт; продовольствие; конкуренция; агротуризм; снабжение.

Хачатрян Левон Рубенович - кандидат экономических наук, научный сотрудник, Европейский университет (Республика Армения, г. Ереван, ул. Давида Анахти, д. 10)

E-mail: levonkhach@yahoo.com

The article has been received 15.11.2019

Revision: 18.11.2019

Бібліографічний опис для цитування:

Khachatryan L. R. Current problems of the agricultural market and development prospects on an example of the Republic of Armenia. Економіка АПК. 2019. № 12. С. $79-86$.

\section{O \\ Обіг сільгоспземель на найближчі 3-5 років слід запроваджувати лише для селян-фізичних осіб - Юрій Лупенко}

Обіг сільськогосподарських земель має запроваджуватися поетапно. Спочатку для селян-фізичних осіб, безпосередньо зайнятих у сільському господарстві, тих, які проживають у сільській місцевості. А вже потім через 3-5 років - для всіх інших покупців, включаючи й юридичних осіб, зазначив директор Національного наукового центру «Інститут аграрної економіки», академік НААН Юрій Лупенко, виступаючи на парламентських слуханнях «Земельна реформа: вітчизняна модель обігу земель сільськогосподарського призначення», які відбулися 4 грудня 2019 року.

На його думку, такий підхід дозволить сформувати на селі потужний середній клас як основу успішного сільського розвитку.

Нині середньорічні доходи сільських домогосподарств і агропідприємств різняться майже у 1500 разів, поінформував науковець. До прикладу, торік грошові доходи одного сільського домогосподарства становили 95 тис. грн, тоді як одного сільгосппідприємства - понад 140 млн грн. Такий дисбаланс унеможливлює їх конкуренцію за умов одночасної участі у купівлі землі. Отже, про участь юридичних осіб у купівлі земель сільськогосподарського призначення можна говорити лише після використання селянами свого переважного права, підсумував Юрій Лупенко.

Запровадження обігу земель сільськогосподарського призначення покликане відродити іпотечне кредитування агровиробництва. Для цього при запровадженні обігу сільгоспземель доцільно створити спеціалізований Земельний іпотечний банк і наділити його функцією купівлі-продажу земельних ділянок для підтримки їх високої ліквідності. Запропонований підхід не лише спростить доступ селян до іпотечного кредитування під заставу землі, а й дозволить підтримувати високу ціну на земельні ділянки в періоди високої пропозиції на ринку, вважає Юрій Лупенко.

Участь іноземців в обігу українських сільгоспугідь доцільно ув'язати зі вступом нашої держави до Європейського Союзу.

Цей варіант можна вважати компромісним в умовах нинішнього статусу української землі, який міг би нівелювати можливі ризики, пов'язані з участю іноземців в обігу сільгоспземель. Такий шлях обрали більшість країн - нових членів ЄС, нагадав науковець.

Прес-служба ННЦ «Інститут аграрної економіки» 